\title{
OR14-V-Uncertainty-PD2La Uncertainty Quantification Workshop Report
}

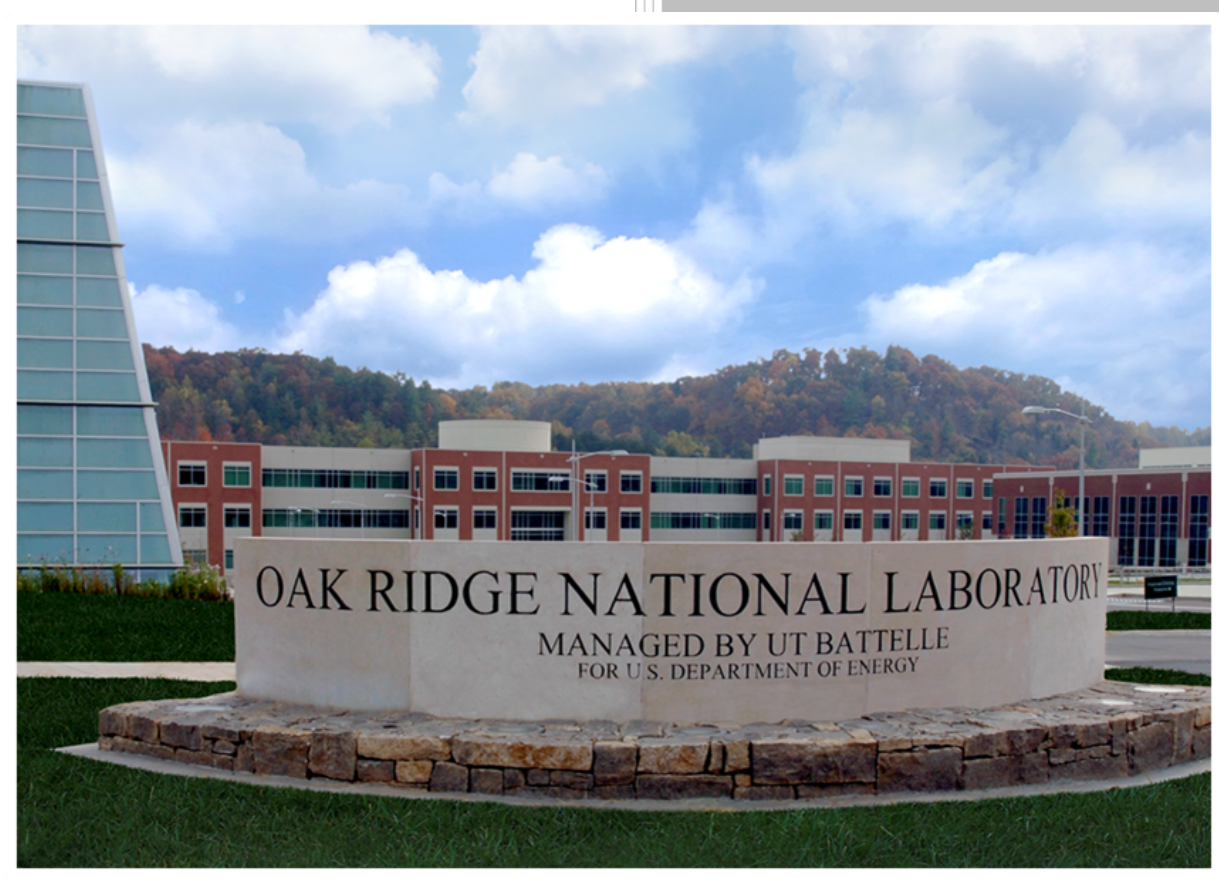

Stephen Croft

Andrew Nicholson

July 2017

Approved for public release.

Distribution is unlimited. 


\section{DOCUMENT AVAILABILITY}

Reports produced after January 1, 1996, are generally available free via US Department of Energy (DOE) SciTech Connect.

Website http://www.osti.gov/scitech/

Reports produced before January 1, 1996, may be purchased by members of the public from the following source:

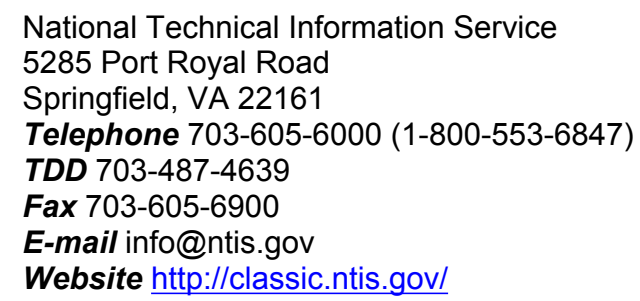

Reports are available to DOE employees, DOE contractors, Energy Technology Data Exchange representatives, and International Nuclear Information System representatives from the following source:

Office of Scientific and Technical Information

PO Box 62

Oak Ridge, TN 37831

Telephone 865-576-8401

Fax 865-576-5728

E-mail reports@osti.gov

Website http://www.osti.gov/contact.html

This report was prepared as an account of work sponsored by an agency of the United States Government. Neither the United States Government nor any agency thereof, nor any of their employees, makes any warranty, express or implied, or assumes any legal liability or responsibility for the accuracy, completeness, or usefulness of any information, apparatus, product, or process disclosed, or represents that its use would not infringe privately owned rights. Reference herein to any specific commercial product, process, or service by trade name, trademark, manufacturer, or otherwise, does not necessarily constitute or imply its endorsement, recommendation, or favoring by the United States Government or any agency thereof. The views and opinions of authors expressed herein do not necessarily state or reflect those of the United States Government or any agency thereof. 
Nuclear Security and Isotope Technology Division

\title{
OR14-V-Uncertainty-PD2La Uncertainty Quantification Workshop Report
}

\author{
Stephen Croft \\ Andrew Nicholson
}

Date Published: July 2017

Prepared by OAK RIDGE NATIONAL LABORATORY

Oak Ridge, TN 37831-6283

managed by

UT-BATTELLE, LLC

for the

US DEPARTMENT OF ENERGY

under contract DE-AC05-00OR22725 



\section{WORKSHOP OVERVIEW}

The Uncertainty Quantification (UQ) research team held the Uncertainty Quantification for Nondestructive Assay Workshop as part of the Advances in Nuclear Nonproliferation Technology \& Policy Conference held in Santa Fe, New Mexico, on September 28-30, 2016. The workshop had 14 speakers, each of whom submitted a paper for publication in the conference proceedings. They gave lectures in the mornings and participated in discussions in the afternoons. Their presentations are listed in Table 1. Forty-three people from the national laboratories, industry, and academia attended the workshop. Their research interests ranged from uncertainties in nuclear data to uncertainties in human reliability.

Table 1. Overview of presentations given at the Uncertainty Quantification for Nondestructive Assay Workshop in Santa Fe, New Mexico, on September 28-30, 2016

\begin{tabular}{|l|l|l|}
\hline Presentation Title & Speaker & Institution \\
\hline $\begin{array}{l}\text { A New Approach to Estimate Uncertainty in } \\
\text { Waste Characterization }\end{array}$ & Biagio Zaffora & CERN \\
\hline $\begin{array}{l}\text { Second-Order Adjoint Sensitivity Analysis } \\
\text { Methodology (2nd-ASAM) Applied to } \\
\text { Quantification of Non-Gaussian Uncertainties in } \\
\text { a Nonlinear Heat Conduction Benchmark }\end{array}$ & Dan Cacuci & $\begin{array}{l}\text { University of South } \\
\text { Carolina }\end{array}$ \\
\hline $\begin{array}{l}\text { Uncertainty Quantification in Human Reliability } \\
\text { Modeling for Security Screening Operations }\end{array}$ & Bryan Stanfill & PNNL \\
\hline $\begin{array}{l}\text { Monte Carlo Uncertainty Quantification for an } \\
\text { Unattended Enrichment Monitor }\end{array}$ & Ken Jarman & PNNL \\
\hline $\begin{array}{l}\text { Plutonium Mass Determination by Neutron } \\
\text { Counting }\end{array}$ & Brian Weaver & LANL \\
\hline $\begin{array}{l}\text { Uncertainty Quantification with the Event-by- } \\
\text { Event Fission Model FREYA }\end{array}$ & Andrew Nicholson & ORNL \\
\hline $\begin{array}{l}\text { Representing the Uncertainty Structure of the } \\
\text { Factorial Moments of }{ }^{252} \text { Cf and 238, 240, 242Pu }\end{array}$ & Stephen Croft & ORNL \\
\hline $\begin{array}{l}\text { Total Measurement Uncertainty Error Budget for } \\
\text { a Tomographic Gamma Scanner }\end{array}$ & John Kirkpatrick & Canberra Industries \\
\hline $\begin{array}{l}\text { Nuclear Data Uncertainty Quantification-a } \\
\text { Practical Example for Nuclear Material } \\
\text { Measurements }\end{array}$ & Martyn Swinhoe & LANL \\
\hline $\begin{array}{l}\text { Using an Inverse Monte Carlo Method to } \\
\text { Determine Measurement Uncertainties }\end{array}$ & Douglas Rodriguez & JAEA \\
\hline $\begin{array}{l}\text { Revisiting Nuclear Fission Data for } \\
\text { Nonproliferation Applications }\end{array}$ & Patrick Talou & LANL \\
\hline $\begin{array}{l}\text { Uncertainty Quantification Implementation in } \\
\text { FRAM }\end{array}$ & Duc Vo & LANL \\
\hline Uncertainties in Coded-Aperture Imaging \\
\hline $\begin{array}{l}\text { Testing for the Poisson Distribution in Neutron } \\
\text { Counting }\end{array}$ & Tom Burr & IAEA \\
\hline
\end{tabular}




\section{WORKSHOP RECOMMENDATIONS AND FOCUS AREAS}

A few general focus areas for further research were addressed:

- Uncertainty Quantification in Measurement,

- Uncertainty Quantification in Models and Simulations,

- Uncertainty Quantification in Nuclear Data,

- Mathematics of Uncertainty Quantification, and

- Communication of Uncertainty Quantification Results and Principles.

Recommendations for each of these focus areas are listed below.

\subsection{UNCERTAINTY QUANTIFICATION IN MEASUREMENT}

There are many applications where sample geometry and shelf shielding can have a significant effect on nondestructive assay (NDA) measurements. These include waste removal/disposal, holdup in enrichment facilities, and fast-neutron multiplicity counting. In the case of waste removal/disposal, the effect of variation in source distribution inside of containers on determined activity distribution is not well understood for techniques like the tomographic gamma scanner (TGS). An extensive measurement/simulation campaign is required to quantify the effect of these systematic uncertainties. In holdup measurement, perhaps the largest generator of uncertainty is deposit geometry. The community would like to create better methods to define geometry and understand how geometry errors affect mass predictions. In addition, the community would like to know if using higher resolution detectors provides more accurate mass predictions. Finally, sample composition may have a large effect on fast-neutron multiplicity counting measurements. The community would like to better understand errors in geometry on mass calculations.

Understanding uncertainties introduced by human factors is very important in NDA measurements. The community would like to understand how the interface between humans and the equipment they use can affect systematic uncertainties. The community would also like to quantify sources of human error and find ways to reduce mistakes.

There is no universally accepted methodology to determine Total Measurement Uncertainty (TMU) in NDA measurements. The community would like to create a guide of best practice and process methodologies to inform operators on the best measurement technique for a given scenario. In addition, systematic errors are rarely quantified. In some situations, systematic errors may be much greater than random errors. Understanding this can help an operator optimize measurement times and use new statistical methods (like bootstrapping or Bayesian methodologies) to quantify sources of error.

New calibration standards and certified reference materials are needed for use in imaging, neutron coincidence counting, and gamma-ray spectroscopy. New certified reference materials for americium in plutonium samples would be useful for mass spectroscopy and gamma-ray measurements. A set of National Institute of Standards and Technology (NIST) traceable standards for calibrating TGS analysis algorithms would be valuable. In neutron coincidence 
counting, ongoing research is being conducted on using ${ }^{252} \mathrm{Cf}$ as a calibration surrogate. This technique relies heavily on understanding uncertainties nuclear data and multiplicity counter measurements. In gamma-ray spectroscopy experiments, understanding efficiency calibration is important but difficult to measure. The community would like to quantify errors in efficiency calibration and how these errors translate into decisions made by analysis codes. In addition, the community believes it is important to produce best practice and process guidelines to inform operators.

\subsection{UNCERTAINTY QUANTIFICATION IN MODELS AND SIMULATION}

The community feels the need to run physics-based models through particle transport codes to quantify uncertainties on experimental observables. In addition, publishing source term definition recommendations may be useful to the community using tools like sources $4 \mathrm{c}$ and high-quality experimental data.

Current models of human error are very squishy and need validation with real world data. The community feels like more work needs to be done by investigating the deviation between models and real-world data.

\subsection{UNCERTAINTY QUANTIFICATION IN NUCLEAR DATA}

The community sees a benefit to using physics-based models like event fission codes (e.g., FREYA) to provide input data for calculations where experimental data does not exist. More work needs to be done with these models to improve input parameters to better match available experimental observables.

The community would like more high-quality nuclear data including neutron multiplicity distributions, energy spectra, and angular gamma-ray and neutron correlations for plutonium isotopes, neutron-induced fission neutron and gamma-ray multiplicity distributions for ${ }^{235} U$ and

${ }^{239} \mathrm{Pu}$, photo-fission data, neutron multiplicity and energy distributions for curium, delayed gamma and neutron data, nuclear resonance fluorescence, and photoelectric cross sections for atoms with high mass $(\mathrm{Z}>91)$.

Gamma-ray branching ratios were singled out as a particularly important need for the community. Available data does not contain covariance information, and there are many contradictory experiments. A set of recommended energy states, with uncertainties, for all isotopes would be a valuable guide for NDA measurements and methodologies.

\subsection{MATHEMATICS OF UNCERTAINTY QUANTIFICATION}

The community is interested in applying Bayesian statistics to NDA measurement analysis to get better UQ. For example, the community would like to see if Bayesian methods can be used in data fusion algorithms or if neutron and gamma-ray data can be combined to get better predictions with coincidence counters. In addition, they would like to know if Bayesian methods can be used to generate full probability distributions and correlations matrices for detection limits and confidence intervals for NDA measurements. 
Inverse Monte Carlo analysis methods are also of interest. Questions from the community include whether inverse modeling techniques used in other fields can be applied to NDA safeguards measurements and how expert judgment and constraints can be applied to these models.

The community is interested in a guide on how to apply bootstrapping methods in NDA, including warning and examples on how to use bootstrapping to investigate systematic errors. This guide should include a procedure to check for failures in the bootstrapping methodologies.

\subsection{COMMUNICATION OF UNCERTAINTY QUANTIFICATION RESULTS AND PRINCIPLES}

The community realizes that best practice guides and standards on reporting on uncertainty estimates is desperately needed in the field. The community sees a need for the American Section of the International Association for Testing Materials (ASTM) C26 Standards Group to create standards for every NDA technique. These standards need to be publicized and made available to the community at large, perhaps through a workshop through ASTM.

In addition to best practice guides, the community would like to see more training for NDA professionals and graduate students in statistical methods. New high-quality information takes time and money to generate, so updating information that is currently available should be a priority.

\section{MOVING FORWARD}

The community would like to identify a few challenge problems and present them at the Institute of Nuclear Materials Management or the European Safeguards Research \& Development Association NDA working groups to spur research in UQ for NDA.

The community would like to continue discussions on the importance of UQ and highlight research that is useful to NDA measurements. A regular workshop or track at future ANS meetings has been proposed. The possibility of meeting at one of the International Atomic Energy Agency (IAEA) meetings has also been suggested. 